\section{NYTT OM LEGEMIDLER}

\section{Løs vår påskerebus!}

Klarer du vår lille påskerebus? De syv løsningsordene er en gruppe legemidler som har det til felles at de utgjør en særlig risiko for eldre. Riktige løsningsord publiseres i neste utgave av Nytt om legemidler og på legemiddelverket.no.

Send dine svar til redaksjonen@legemiddelverket.no innen mandag 13. april. Da er du med i trekningen av et Universal gavekort på kroner 500,-.
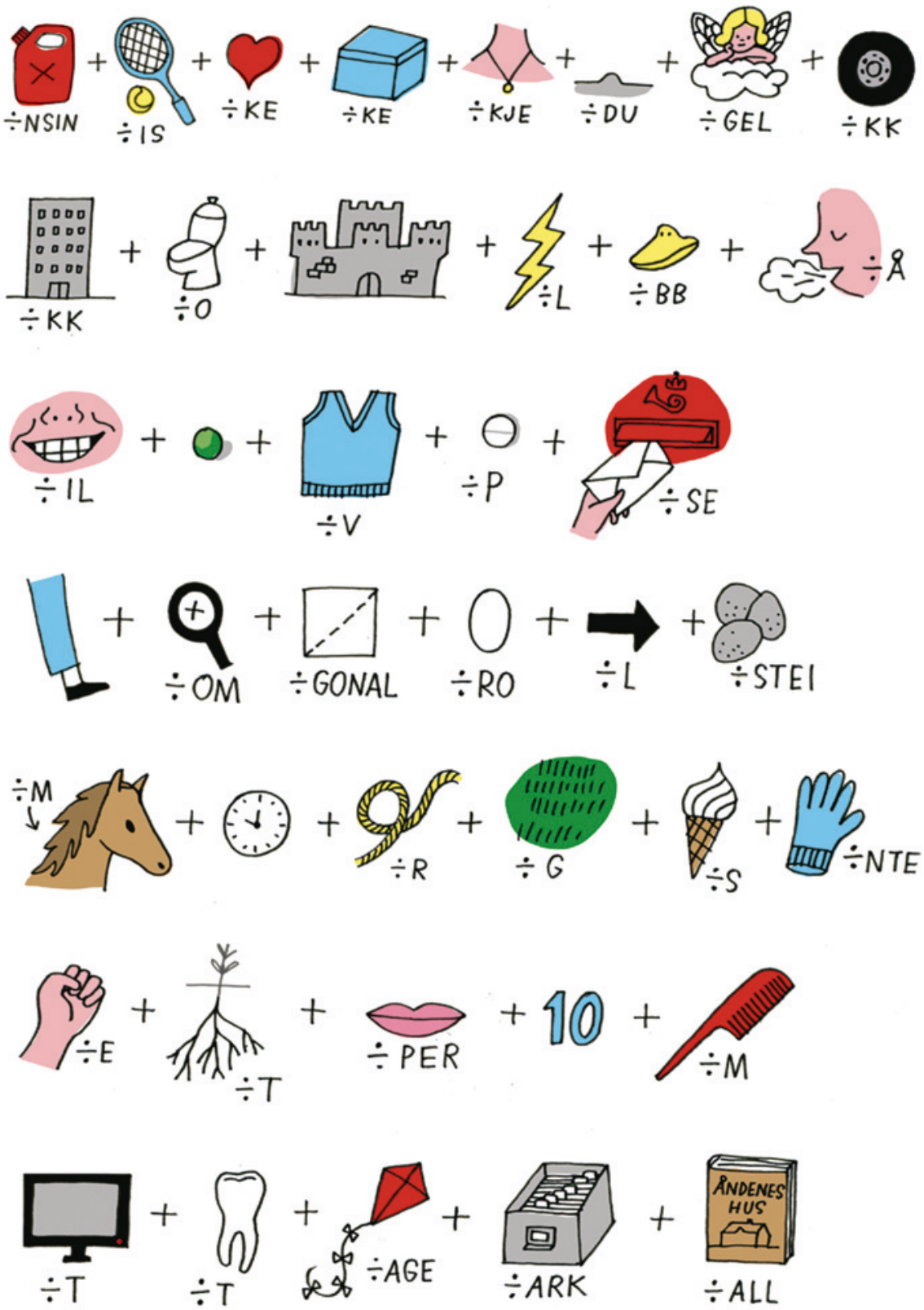

Illustrasjoner: Kristin Roskifte

\section{Legemiddelgjennomgang}

Eldre behandles ofte for flere sykdommer og må derfor bruke mange legemidler samtidig. Det øker faren for bivirkninger og interaksjoner. For å sikre god behandling og forebygge pasientskader, bør pasienter som bruker mange legemidler ha en legemiddelgjennomgang (LMG). LMG bør gjennomføres ved endringer i pasientens tilstand, ved bytte av omsorgstilbud og ellers minst en gang i året. Dette er en løpende oppgave for behandlende lege, og fastlegen har et særskilt ansvar. Det er innført takst i Normaltariffen (2ld) for arbeidet, og for å gjøre det enklere har Legemiddelverket laget en kort sjekkliste i tosidig A4-format.

Last ned sjekklisten på legemiddelverket.no/sjekkliste eller bestill ved å sende e-post til redaksjonen@legemiddelverket.no.

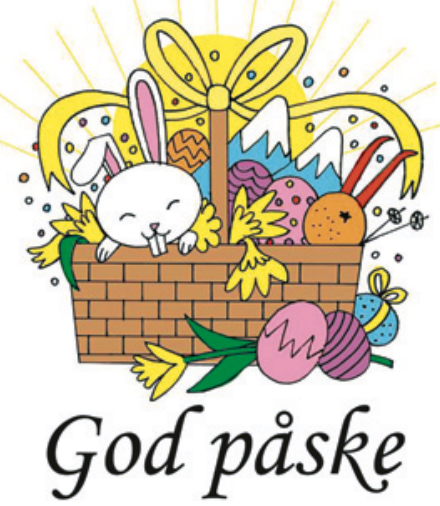

HPV-vaksinen Gardasil for menn Gardasil fikk kjønnsnøytral indikasjon i juni 2014 etter at kliniske studier viste at vaksinen har effekt mot kjønnsvorter og premaligne anale lesjoner (1). Fire tusen menn mellom 16 og 26 år deltok $\mathrm{i}$ studier som undersøkte i hvilken grad Gardasil beskyttet mot kjønnsvorter og intraepitelial neoplasi i anus (AIN) og penil/perineal/perianal neoplasi (PIN).

\section{Kjønnsvorter}

Gardasil hadde best effekt hos de som ikke var smittet med aktuelle HPV-typer ved studiestart. Hos disse (naive) reduserte Gardasil forekomsten av kjønnsvorter som skyldtes HPV 6/11/16/18 med $89,3 \%$ (95 \% KI 65,3-97,9). Beskyttelsen i gruppen sett under ett var lavere (68\%). Median oppfølgingstid var 2,9 år.

Studiene ga ikke svar på om Gardasil beskytter mot PIN. Dette skyldtes for få tilfeller. Det var ingen tilfeller av PIN i gruppen som fikk Gardasil mot fire i kontrollgruppen.

\section{Anal neoplasi}

Effekten mot anal intraepitelial neoplasi (AIN) grad 1/2/3 ble studert i en undergruppe på 598 menn som hadde sex med menn. Median oppfølgingstid var 2,15 år.

I denne undergruppen var $61 \%$ av mennene ikke smittet med de aktuelle HPV-typene ved studiestart. Hos disse naive reduserte Gardasil forekomsten av AIN grad 2/3 som skyldtes HPV 6, 11 , 16,18 med $74,9 \%$ (3/194 mot 13/208 med placebo). Når man inkluderte de som allerede var smittet $i$ analysen, var beskyttelsen lavere $(54,2 \%)$.

Folkehelseinstituttet skal vurdere om Gardasil også skal tilbys gutter i vaksinasjonsprogrammet.

Referanse:

1. Preparatomtalen.

\section{Statens legemiddelverk} Norwegian Medicines Agency 